PLURAL, Revista do Programa de Pós-Graduação em Sociologia da USP, São Paulo, v. 16, n. 1, pp. 93-109, 2009

\title{
Uma Etnografia Multissituada das Práticas Populares de Consumo
}

\section{Cláudia Sciré*}

Resumo: Este trabalho tem o objetivo de discutir um modo de fazer etnográfico realizado em uma pesquisa sobre práticas populares de consumo, desenvolvida em uma região periférica da cidade de São Paulo. Pelo acompanhamento de um artefato específico - o cartão de crédito - e das práticas que se desenrolam a partir dele, procura-se demonstrar, ao longo deste artigo, a possibilidade de construir uma análise que articule questôes globais com questôes próprias ao campo de observação empírica, sem cair em uma dicotomização das categorias de riqueza e pobreza, exclusão e inclusão, local e global. Assim, a análise aqui apresentada pretende contribuir com novas questôes sociológicas que cruzam as fronteiras do campo etnográfico tradicional.

Palavras-chave: práticas de consumo; modos de vida; artefatos; etnografia; metodologia de pesquisa.

\section{A Multi-Sited Ethnography about the Popular Consumption Habits}

Abstract: This work intents to discuss an ethnographical practice, which was developed in a research about the consumption habits of the habitants of a slum area in São Paulo.

Following a specific artefact - the credit card - and the practices that take place from it, we will try to demonstrate the possibility to build an analysis able to encompass global aims with questions concerning the field of empirical observation, avoiding a dichotomization of the categories of wealth and poverty, exclusion and inclusion, local and global. Thus, the analysis presented here aims to contribute to new sociological questions that cross the boundaries of traditional ethnographical fieldwork.

Keywords: consumption habits; ways of life; artefacts; ethnography; research methodology.

\footnotetext{
* Mestrado em Sociologia pela Universidade de Sáo Paulo.
} 


\section{INTRODUÇÃO}

Este artigo tem como objetivo explanar e discutir um modo de fazer etnográfico, a partir dos resultados de uma pesquisa de mestrado, que buscou compreender e analisar as práticas de acesso ao consumo entre os moradores de uma região situada na periferia paulistana. Para isso, buscou-se analisar as práticas de aquisição de bens, atentando para a gestão dos orçamentos domésticos e para os impactos gerados a partir dos mecanismos de concessão de crédito .

Dessa forma, este artigo procura apresentar alguns resultados da pesquisa empreendida paralelamente à discussão metodológica sobre a construção e delimitação do objeto de investigação e sobre a forma como os dados empíricos foram interpretados e analisados. $\mathrm{O}$ intuito é demonstrar a possibilidade de construir uma análise que articule diferentes escalas de um mesmo problema, a saber, questóes globais - como os fluxos de capital globalizado - com as formas cotidianas de viraçáo e gestão de recursos no interior do orçamento doméstico.

Para isso, haverá à disposição cenas descritivas, construídas a partir de situações encontradas em campo e atreladas a duas referências metodológicas importantes: a etnografia multissituada de George Marcus (1998) e a noçáo de "artefatos" de Bruno Latour (1994). Juntas, essas duas noçóes forneceram inspiração para encarar e analisar, de uma perspectiva mais ampla, um processo presente no mundo popular, até o momento pouco explorado - a proliferaçáo dos mecanismos de concessão de crédito, mais especificamente, os cartôes.

Em um primeiro momento, discute-se de que forma parte da literatura tem encarado o desafio de realizar etnografias no mundo globalizado. Tal discussão ajudou a iluminar a realização de um trabalho cujo objeto, por si só, remete a processos mais amplos. Em seguida, aborda-se de forma mais detalhada aquilo que constituiu a inspiração metodológica deste trabalho - a noção de artefatos - e as práticas que podem se desenrolar a partir daí.

Por fim, parte-se para uma descrição etnográfica dos cartóes e de seus usos. Pretende-se, assim, mostrar como tal artefato constitui um objeto capaz de remeter a planos e escalas distintos, revelando processos e práticas que se estendem para além do campo de observação empírica e que merecem, igualmente, ser considerados ao analisar o fenômeno do consumo popular. Espera-se, assim, contribuir com novas questôes sociológicas que cruzam as fronteiras do campo etnográfico tradicional.

\section{CONSUMO POPULAR, FLUXOS GLOBAIS}

Compras realizadas em grandes hipermercados e shopping centers, consumo de modernos eletrodomésticos, bem como celulares, câmeras digitais, $\mathrm{MP}_{3}$, por meio da utilização maciça de

\footnotetext{
I A investigação propunha averiguar de que forma o acesso ao consumo e a seus espaços ocorre, dentro de um contexto permanente de escassez de recursos, que permeia a vida das populaçóes mais pauperizadas, residentes nas periferias, ao mesmo tempo em que múltiplas oportunidades de aquisiçẫo de bens e de acesso a espaços de consumo proliferavam. Para maiores detalhes, consultar Sciré (2009).
} 
mecanismos de crédito, constituem-se como alguns dos elementos que ajudam a caracterizar o fenômeno do consumo popular nos anos 2000.

É claro que não se pode excluir desse quadro as práticas tradicionais de aquisiçãa de bens (em mercadinhos e com vendedores de porta em porta, por meio do famoso fiado, etc.). Contudo, o que a pesquisa permitiu apontar é como essas práticas têm cada vez mais se mesclado com outras, tidas como mais "financeirizadas".

O caso de Lúcia e de sua filha Lílian ajuda a ilustrar algumas características das formas de vida nas quais muitas famílias entrevistadas se encontram.

Lúcia, 39 anos, é baiana, trabalha como copeira e tem três filhas, de dezenove, dezoito e oito anos. A mais velha é Lílian, que, por sua vez, tem um filho de três anos. A família vive em uma casa de quatro cômodos e tem uma renda mensal de aproximadamente mil reais. Lúcia é a chefe da família e cria as filhas sozinha. Lílian não recebe pensão do pai da criança e conta com a ajuda de sua mãe para sustentar seu filho.

Diante dessa conjuntura, Lúcia sempre buscou ter uma rendinha extra que ajudasse no orçamento da casa. Em uma época, ia à Rua 25 de Março comprar bijuterias para vender. Hoje, garante náo ter mais tempo para isso, por conta dos estudos. Mesmo assim, quinzenalmente, faz faxina aos sábados, na casa do patrão - ganha cinquenta reais por dia - e ainda costura para fora. Não que tenha uma clientela ampla, mas, às vezes, alguma amiga pede uma ajuda para fazer uma barra, pregar um botão, para cortar um pedaço de roupa, e aí já são mais alguns trocados. Além disso, ela vende trufas e pães de mel na empresa em que trabalha. Paga um real de cada um e vende por um real e cinquenta.

Lílian também tentava se virar como podia durante a adolescência - fazia alguns bicos e chegou até a vender Avon -, até que conseguiu seu primeiro emprego fixo em uma casa lotérica, no bairro do Campo Belo.

Se a renda obtida com essas atividades é extremamente significativa na composição da renda final da família, essas estratégias convivem, nos dias atuais, com novas práticas. Vejamos.

Por determinado período de tempo, as despesas mensais de Lúcia se dividiram da seguinte forma: trezentos e cinquenta reais com as compras de mercado do mês, cento e cinquenta reais com a babá de sua filha caçula e do neto; quarenta e nove reais com seu celular retirado nas Casas Bahia em dez parcelas; setenta e cinco reais com o aparelho de som também da mesma loja, retirado em onze parcelas.

Para Lúcia, a divisão das compras em várias parcelas constitui-se como a única possibilidade de adquirir bens, uma vez que "pagar à vista é coisa de rico". Além dessas despesas fixas, havia gastos com roupas para as filhas e o neto nas lojas Eskala, Lojão do Brás, A Japonesa (em Santo Amaro), Marisa e C\&A.

Fora a babá, todos os gastos de Lúcia são pagos no cartão. As compras de supermercado, quando feitas no Compre Bem, são pagas com o cartão do supermercado. Quando são feitas no Satmo ou em outro mercado, são pagas com seu Credicard, com o qual paga também a maior parte de suas despesas. Esse cartão chegou por meio de uma proposta, após Lúcia pegar um 
empréstimo de duzentos e cinquenta reais na financeira Fininvest. Após pagar, recebeu o cartáo e continuou usando-o. Isso já remontava há cerca de três anos.

Lúcia ainda tem o cartão Visa das Casas Bahia, que conta com um limite de mil e quatrocentos reais para compras dentro da loja e de novecentos reais para compras fora da loja, além dos cartôes das lojas Marisa, C\&A e Renner.

Lílian, por sua vez, conta com o cartáo de crédito adicional que a mãe solicitou para ela, com o qual compra fraldas para o filho, quando náo dispóe de dinheiro no momento. No caso dessas despesas, até que ela arranjasse um emprego fixo, Lúcia era quem pagava a fatura. Depois do novo emprego, sabendo que teria a possibilidade de pagá-la, aproveitou para comprar mais coisas no cartáo. No entanto, Lílian tira proveito da rede de relaçóes que possui com algumas vendedoras do bairro para adquirir produtos - roupas e calçados para o filho, peças de lingerie, produtos de beleza da Avon e da Natura - e pagar depois.

\section{ETNOGRAFIAS GLOBAIS DO SISTEMA MUNDIAL E NO SISTEMA MUNDIAL: A ETNOGRAFIA MULTISSITUADA}

A situação previamente descrita reflete o quanto uma pesquisa que se proponha a tratar das práticas de consumo das populaçóes mais pauperizadas (e não só delas) - e, consequentemente, das formas de lidar com a renda, com o orçamento doméstico e com a aquisição de bens - força o pesquisador a considerar náo só o grupo estudado, no interior de uma localidade específica, isto é, o local escolhido para se realizar o trabalho de campo ${ }^{2}$. Em primeiro lugar porque o estudo das práticas de consumo pressupóe, por si só, considerar múltiplos aspectos de diferentes ordens como as estratégias econômicas e financeiras para atrair consumidores; os mecanismos existentes no mercado; a localizaçáo específica de certas redes de consumo; além do acompanhamento propriamente dito das agendas de consumo, das trajetórias de compras de diversos tipos, da utilização dos meios de pagamento, etc.

Em segundo lugar, um trabalho que pretenda compreender e analisar as práticas deve apelar para um tipo de procedimento de pesquisa e de análise de dados que náo se detenha ao plano "micro" ou "macro", mas que permita olhar para dados que não parecem, à primeira vista, pertencer ao repertório social estudado - como as cadeias de mediaçóes e os artefatos -, recorrendo, assim, a outros tempos, objetos e atores e acompanhando uma cadeia de elementos que ultrapassam o campo de observação empírica, propriamente dito.

\footnotetext{
2 Embora o campo de observaçáo empírica escolhido para a pesquisa se localize em um ponto específico da cidade, no distrito do Campo Limpo, zona sul de São Paulo, próximo a um equipamento de consumo recém-inaugurado (Shopping Campo Limpo), e o trabalho de campo tenha sido realizado nesse local - tentando traçar os fios que permitissem reconstituir as relaçóes que existem entre as mudanças nas práticas de consumo, a partir do surgimento desse equipamento -, a pesquisa náo deixou de ser multissituada, isso porque as informaçóes obtidas no trabalho de campo e os relatos ouvidos permitiram à pesquisadora enxergar processos que estáo conectados às práticas populares de consumo e que se referem, igualmente, à existência de certos fatores que se encontram presos a outros fios dessas redes, situados em outras dimensóes, para além do espaço pesquisado.
} 
Isso significou, dentro do âmbito da pesquisa realizada, olhar para os arranjos das práticas cotidianas de consumo e buscar os elementos que se ligam a eles, elementos que, muitas vezes, situam-se em outros contextos, fazendo referência a quadros espaço-temporais de ordens distintas ${ }^{3}$.

Dessa forma, buscou-se seguir determinada escolha metodológica que reconhece a importância de identificar quais as noçóes macro que estáo presentes nos âmbitos locais e a forma como se apresentam nas práticas de consumo, sem permanecer, contudo, nessas noçóes, pois o intuito náo era realizar uma análise que partisse "de cima" - uma etnografia do consumo no capitalismo globalizado ${ }^{4}$.

Optou-se, assim, não só por olhar para as construçôes e negociaçôes cotidianas, que revelam a forma como as dimensôes globais são vividas no dia a dia pelas pessoas (BURAWOY, 2000; LAUSER, 2005), mas também traçar linhas e fios que permitissem visualizar essas mediaçóes entre espaços e contextos sociais, de forma que o domínio macro dos sistemas sociais se tornasse incorporado e articulado, no espaço das etnografias, ao domínio das práticas locais (MARCus, 1995, p. 97).

Como mostra George Marcus (1995), as atuais pesquisas interessadas em mudanças culturais e sociais em âmbitos locais necessitam desenvolver estratégias empíricas que considerem pessoas e símbolos, ultrapassando lugares e fronteiras e estabelecendo conexóes ao longo de várias escalas etnográficas.

A referência teórico-metodológica de etnografia multissituada de George Marcus serviu, portanto, como eixo orientador não só da pesquisa de campo, como também da forma como os dados colhidos foram interpretados e apresentados. Segundo Marcus, o pesquisador deve seguir as cadeias, as trajetórias e os fios que fazem parte de um fenômeno específico e tratar de fazer conjunçôes ou justaposiçóes de situaçôes, estabelecendo uma conexão ou associação entre elass (Ibidem, p. IOs).

3 Trata-se, é claro, de uma opçáo de pesquisa que se orienta pelo estudo de práticas, ao tomar como referência as noçóes de mediaçóes, vinculaçóes e artefatos de Latour (1994; 1999). Tais noçóes ajudaram a desenvolver a prática de pesquisa e de análise de dados, pois permitiram considerar os movimentos circulatórios dos artefatos, por meio de redes e conexóes diversas, e trabalhar com diferentes referências espaço-temporais e em diversos níveis de materialização. Segundo Latour, esse tipo de análise acaba dispensando as noçôes de micro e de macro, indivíduo ou sociedade, atividade ou passividade dos sujeitos diante das estruturas, pois o que está em questão são seus vínculos e sua natureza. Assim, em vez de olhar para as práticas de consumo como sendo reflexo de formas de dominação e alienaçáo dos indivíduos ou de sua liberdade e criação de significados culturais, recorreu-se às mediaçôes às açôes distribuídas pelos diversos nós da rede, por meio das quais as práticas de consumo ganham uma dimensão mais real, pois são captadas em sua dinâmica de circulaçáo, em vez de um encadeamento de conceitos. Dessa forma, foi possível focalizar determinados processos e globalizar outros, puxar determinadas referências, analisando as açóes engendradas pelos objetos, indo sempre de um ponto a outro e nunca deixando de realizar movimentos circulatórios, ao longo de determinada cadeia. ${ }_{4}$ Embora ela também seja possível, por meio do estudo das práticas, náo foi este o objetivo proposto para esta pesquisa. $5 \mathrm{O}$ objeto da pesquisa não é, assim, necessariamente, restrito a determinado grupo situado no interior de um campo de observação. Muitas vezes, o objeto consiste em um determinado fenômeno social (como, por exemplo, as práticas de consumo), e sua construçáo ocorre ao se fazerem determinados movimentos (por meio de passos já previamente planejados ou oportunistas), seguindo pessoas, histórias, objetos, ao longo de várias cadeias, superpondo situaçóes e verificando os pontos nos quais as intersecçóes, ressonâncias e associaçōes ocorrem (MARCUS, I995, p. I06). 
Foram adotados, dessa forma, alguns passos sugeridos por Marcus, como seguir pessoas, suas histórias e biografias. Como mostra Lauser (op. cit.), olhar para as histórias de vida é importante, pois, seguindo seus rastros, quando as pessoas refletem e ordenam suas experiências individuais, o pesquisador é forçado a ficar atento às conexôes temporais e espaciais existentes entre espaços e contextos sociais diversos. Em suma, isso significa que a interpretação das trajetórias urbanas e de consumo dos entrevistados permite antevê-las como espaços de condensaçáo de práticas e de açóes, ajudando a construir cenas nas quais certos processos podem ser flagrados (Telles, 2006, p. 54).

Foram, então, essas tramas narrativas - fontes ricas de conexōes, reveladoras de justaposiçóes de contextos sociais por meio de uma sucessão de experiências individuais narradas no trabalho de campo (MARCUS, 1995, p. I09) - que serviram de fonte para a construção dos relatos etnográficos.

Isso não significa que todos os locais precisem ser tratados com o mesmo conjunto de práticas de trabalho de campo, sendo investigados com a mesma intensidade, pois a etnografia multissituada é inevitavelmente o produto de bases de conhecimento de várias intensidades e qualidades (Ibidem, p. Ioo).

É possível, também, adotar uma prática de pesquisa que Marcus denomina "etnografia estrategicamente situada" - que não considera uma mudança literal dos locais de investigação ou a etnografia realizada em múltiplos espaços -, que trabalha com um contexto multissituado, já que o que ocorre nele não deixa de estar inserido e imbricado em um traçado de redes e no intercruzamento de processos e práticas, mediaçóes, conexôes e circuitos. Como estes não permanecem encapsulados em seus contextos imediatos de referência, também acabam sendo considerados.

O importante a ser notado é que o entendimento das dinâmicas locais de um determinado fenômeno social supóe (e exige) seguir empiricamente essas linhas entrelaçadas que o compóem, mas que transbordam de maneira ampla o perímetro local, justamente porque fazem o traçado de redes superpostas, de escalas variadas, que atravessam e definem (ou redefinem) cada situaçáo.

A realizaçáo da etnografia multissituada náo se restringe, assim, apenas à prática de campo; engloba também o fazer, a forma de relatar o que se ouviu. O "seguir as linhas" refere-se ao trabalho do pesquisador, no momento de analisar os dados. Trata-se de uma tarefa sua olhar para determinados aspectos, estabelecendo associação entre locais e fatos e fazendo escolhas que permitam a construçáo de determinada situaçáo, na qual diferentes facetas de um mesmo fenômeno dialoguem entre si e se sobreponham. É nessa prática de recomposição de múltiplas perspectivas e situaçóes, realizada pelo pesquisador, que as configuraçôes que moldam o fenômeno social vão ganhando sentido.

\footnotetext{
6 No âmbito da pesquisa desenvolvida, acreditou-se que o etnógrafo precisasse "abrir os olhos e os ouvidos" ao que o campo e seus entrevistados the diziam, indo atrás de pistas, que, muitas vezes, não correspondiam às suas ideias preconcebidas. Assim, foi necessário saber olhar para as relaçôes, segui-las e perceber se serão importantes para a construção e a definição do fenômeno social que se pretendia estudar.
} 


\section{A CONSTRUÇÃO DO OBJETO MULTISSITUADO: SEGUINDO HISTÓRIAS, ARTEFATOS, TRAÇANDO TRAMAS DE RELAÇÕES}

A forma e a amplitude das práticas de consumo realizadas pelos entrevistados não estavam totalmente claras de início, mas tornaram-se concretas a partir do momento em que se passou a seguir alguns fios das cadeias referentes às formas de aquisiçáo de bens.

O ponto de partida para isso, por sua vez, consistiu na confecçáo de cenas descritivas e na elaboração de certas situaçóes sociais que permitiram descrever o traçado desse conjunto de processos e práticas, mediaçôes, conexôes e circuitos que compóem o consumo popular. Para isso, consideraram-se, igualmente, não apenas as histórias e práticas dos entrevistados, mas os artefatos que mobilizam. São eles que permitem que tais práticas ocorram da forma como ocorrem.

Náo se pode esquecer que por todas essas histórias perpassam vínculos de relaçôes, por meio de diferentes formas de conexão e interconectividade que possibilitam a circulação de objetos, bens e mercadorias por meio das redes, das mediaçóes sociotécnicas.

No caso da cena apresentada no início, a história de Lúcia e sua filha ajuda a antever que o consumo popular encontra-se ancorado não somente em práticas tradicionais de aquisiçáo de bens. Pelo contrário, os fluxos da riqueza "financeirizada" parecem estar conectados, em vários nós, às práticas populares de consumo. E o que permite evidenciar essa situação é o conjunto de práticas balizadas e ancoradas em determinado artefato - os cartôes.

Segundo Latour (1994), os objetos carregam uma história, não sendo apenas intermediários - simples transferências de uma força que deveria vir de outras fontes -, mas atores sociais de pleno direito. Eles circulam por diferentes contextos e deixam, nessa circulaçáo, uma variedade de significados. Fazendo uso das ideias de Latour, torna-se, então, possível voltar o olhar para determinados nós da rede, olhar para as mediaçóes encadeadas por determinados artefatos e, conforme o interesse, localizar ou globalizar o ponto observado (recorrendo a outros elementos, tempos, lugares e atores).

Dessa forma, optou-se por seguir os cartōes e rastrear seus usos, seguindo os fios de outras tantas tramas de relaçóes que estáo presas a eles. Ao acompanhar objetos como os cartóes, suas peregrinaçốes e os espaços nos quais eles são utilizados, chegou-se ao traçado de trilhas e pontos que conformam as redes de consumo existentes na vida dos pesquisados, as relaçóes estabelecidas entre os que os possuem e os utilizam, os espaços frequentados, os bens adquiridos e as dívidas existentes. É assim que a etnografia dos cartōes constituiu um ponto decisivo para a descriçãoo das práticas e relaçôes sociais permeadas pelo consumo.

\section{O ARTEFATO DO CARTÃO}

"Eu acho bom porque consegue parcelar. Porque à vista é impossível comprar. A gente não consegue comprar à vista."

Lúcia 
A posse dos cartôes de lojas e/ou de crédito das mais diferentes lojas e bandeiras constituise como uma regra que caracteriza o status não só da família de Lúcia, mas de muitas famílias entrevistadas ${ }^{7}$. A maioria dos entrevistados possui em média cinco cartôes, entre os de crédito e os de loja ${ }^{8}$. Abaixo a relaçáo dos tipos de cartốes que mais se encontram presentes, seguidos de uma breve explicação sobre eles.

\title{
Cartōes de lojas:
}

I. Supermercados Satmo. O cartão é oferecido em parceria com a financeira Losango. Não é possível parcelar a compra, pois ele só pode ser usado na loja.

2. Marisa. Só pode ser usado na loja.

3. C\&A. Só pode ser usado na loja e em lojas Drogasil e Mc Donald's.

4. Compre Bem. O cartão é oferecido em parceria com a Taií (financeira do Banco Itaú).

Pode ser usado em qualquer loja do Grupo Pão de Açúcar.

5. Lojas Pernambucanas. Só pode ser usado na loja.

Cartôes de lojas e de crédito, com possibilidade de utilização em outros locais:

6. C\&A. O cartão de crédito é oferecido em parceria com a financeira Ibi.

7. Ponto Frio Unicard. O cartão de crédito é patrocinado pelo Unibanco.

8. Casas Bahia. O cartão de crédito é patrocinado pelo Bradesco.

\begin{abstract}
7 Não se pode esquecer de que esse fenômeno se relaciona com dois outros eventos situados em planos mais globais. Trata-se, primeiramente, da expansão do mercado de crédito nos últimos anos, que partiu da estabilização da economia e do sistema financeiro brasileiros. A partir de meados da década de 1990, assistiu-se a um aumento da oferta de produtos financeiros aos mais pobres, como contas-poupança e contas simplificadas (ZerRENNER, 2007). Esse movimento gerou o alargamento dos prazos de pagamento e novas formas de concessão de crédito, com juros mais baixos e estáveis. Paralelamente a isso, na outra ponta do mesmo processo, observa-se a associação das redes de varejo aos bancos. Os bancos passaram a criar suas próprias financeiras e a atuar junto às lojas de varejo (SANTOS, 2007). $\mathrm{O}$ acordo das lojas com os bancos tornou-se uma forma de garantir o fortalecimento das operaçóes de concessão de crédito aos clientes, sem o comprometimento dos lucros das redes, pois possibilitou às redes varejistas a transferência da carteira de crédito aos bancos, a partir da ampliação da oferta de produtos financeiros (QueIroz, 2007, p. 42). Para os bancos, esse negócio também gerou vantagem, pois passaram a incluir uma parcela importante da população em seus bancos de dados, estando aptos a obter informaçóes sobre clientes potenciais, que, mesmo sem possuir conta aberta, podem ser avaliados como futuros clientes "bons pagadores". É preciso salientar que isso, em grande parte, só foi possível em decorrência da existência dessas redes de monopolistas, tanto no varejo quanto no setor bancário, que concentram grande quantidade de capital, organizando e gerindo altíssimos fluxos de renda. O que se observa é o quanto tal projeto conecta-se diretamente à lógica da concessão de crédito, pois conta com os cartôes, que sáo os artefatos pelos quais é possível visualizar essa aliança entre bancos, financeiras, redes varejistas e administradoras e entender o porquê da expansão exponencial da utilização do crédito como meio de pagamento.

8 Trata-se do tanto de cartóes híbridos, ou seja, cartôes de crédito que podem ser usados nas redes varejistas e também fora delas como cartóes de marca própria (cartões apenas de lojas que fornecem desconto na aquisiçáo de determinados produtos). No caso da rede varejista Casas Bahia, por exemplo, o banco financiador é o Bradesco, por meio da financeira Finasa. Já no Grupo Pão de Açúcar, trata-se dos Bancos Itaú/Unibanco, com a financeira Taií. Há, ainda, uma série de outras associaçōes entre varejo, bancos e financeiras. Para maiores detalhes, consultar Santos (2007).
\end{abstract}


9. Marisa. O cartão de crédito é patrocinado pelo Itaú.

Cartôes de financeiras:

Io. Finivest especial. Cartão de crédito e para saques, oferecido em parceria com o Unibanco.

II. Taií Itaú. Cartão de crédito e para saques, oferecido em parceria com o Itaú.

A trajetória de aquisição desses cartões é bastante diversa, devendo-se a inúmeros fatores. Alguns deles são "fornecidos" pelas lojas das quais já são clientes há algum tempo (como as Casas Bahia, por exemplo, que resolveram oferecer cartôes de crédito a todos os seus clientes do crediário) como uma "vantagem" na hora de parcelar as compras.

Outros aparecem quando se abre uma conta em banco (a taxa de "bancarização" entre os entrevistados também é alta, havendo, por vezes, contas abertas em mais de um banco) ou quando se solicita empréstimo em uma financeira. Há, ainda, os convites para cadastro, que chegam pelos Correios ou depois de telefonemas. Os cartóes também podem ser solicitados pelos próprios entrevistados, quando sentem necessidade de possuí-los, seja nas lojas nas quais fazem as compras, seja no banco em que possuem conta, seja pelo contato com alguma administradora de cartáo.

Apesar de muitos cartôes terem sido feitos a partir de uma oferta da loja ou do banco, não se pode afirmar que seus possuidores foram passivos nesse processo, pois partiu deles a aceitaçáo do pedido e a posterior utilização desses mecanismos.

O que pode ser notado é que certo número de pessoas vem fazendo uso dos cartões não só porque quer ter acesso às vantagens do parcelamento ${ }^{9}$, mas também para poder tirar proveito de um valor (na verdade fictício) que náo possui no momento, mas que se coloca disponível por meio do crédito concedido por esses objetos.

Observou-se, assim, que os cartóes atuam de forma a garantir uma margem maior de manobra no manejamento dos gastos mensais, gerando alteraçốes significativas na gestão do orçamento doméstico e nas relaçóes com a renda e a poupança que se estabelecem no interior da família.

A história de Sônia, apresentada a seguir, ajuda a evidenciar algumas práticas populares existentes no âmbito doméstico, conformadas pelos cartóes.

Sônia, 43 anos, é cearense e vive com os três filhos (de dezessete, quinze e sete anos) em uma casa de três cômodos, recém-adquirida na favela. Sendo mãe e pai ao mesmo tempo das crianças, é a única responsável pela casa e pelos gastos da família, uma vez que os pais de seus

9 Se parcelamento no carnê em várias vezes e com juros já constituía um agente facilitador da aquisição de bens de consumo - pois o que parece importar é que o valor da parcela se encaixe no rendimento mensal -, pode-se supor que, agora, a partir da proliferação dos cartôes de crédito entre esse segmento da populaçáo, o parcelamento tenda a atuar como elemento dinamizador do processo de aquisição de bens, cujo valor à vista não caberia no orçamento, considerando a renda líquida familiar. 
filhos não lhe pagam pensáo. Para dar conta das despesas e satisfazer as vontades de seus dois filhos adolescentes, Sônia trabalha em dois empregos. Em um deles é empregada doméstica e, no outro, trabalha como terceirizada, na parte de limpeza, em uma agência bancária.

Sônia ganha um pouco mais que um salário-mínimo em cada um deles, o que totaliza, no final do mês, novecentos e cinquenta reais. Sua casa possui TV, DVD, computador (doado pela patroa), máquina de lavar, micro-ondas, geladeira e fogáo. Pergunta-se, entấo: como Sônia consegue gerenciar sua renda, de modo que consiga "passar bem" o mês até receber o próximo salário?

Um de seus "truques" está em saber manejar o uso dos diversos cartôes que possui. A seguir, a relação deles:

I. Cartão de crédito Visa (lojas Casas Bahia ${ }^{\mathrm{I}}$ ). Limite do cartão: mil e quinhentos reais (dentro da loja) e quinhentos reais (fora da loja).

2. Cartão de crédito Master Card (loja C\&A).

3. Cartão de débito do banco.

4. Cartão de loja (supermercado Compre Bem).

5. Cartão de loja (hipermercado Extra).

6. Cartão de loja (supermercado Satmo).

7. Cartão de loja (Marisa). Limite do cartão: mil duzentos e cinquenta reais.

Além dos cartôes, Sônia tem conta em banco e uma poupança, pois estava juntando dinheiro para comprar uma casa maior. Como o banco percebeu que tinha renda, mandaram-lhe mais cartốes de crédito. No entanto, para não gastar, ela decidiu não desbloqueá-los, mas mantê-los guardados, caso houvesse um período de dificuldades financeiras. Isso porque, como se pode perceber, os limites dos cartôes são superiores ao seu salário - o que dá margem para que gaste mais do que tem. Além disso, pode-se utilizar o dinheiro para algumas despesas e o cartão para outras, sem que a quantidade de dinheiro restante seja suficiente para pagar a fatura do cartão. Aí é que as dívidas começam a se acumular.

Agora, vejamos como Sônia organiza suas despesas mensais.

Io A rede de móveis, eletrodomésticos e eletrônicos Casas Bahia é uma das redes que mais faturam nesse segmento no Brasil. Sua proposta sempre teve como "alvo" as classes sociais menos favorecidas, e seu dono, Michael Klein, enriqueceu e conseguiu expandir a rede a partir do momento em que descobriu que os mais pobres consumiriam, mesmo pagando um preço mais caro no final, se lhes fosse dada a oportunidade de pagar baixas prestaçóes por mês. Assim, é possível dividir compras em até doze vezes, com parcelas baixíssimas, mas que, se somadas, ao final, resultam em um valor quase $50 \%$ mais caro que o valor original. A concessão de crédito aos consumidores é relativamente simples e não exige comprovante de renda. Quanto mais o consumidor paga em dia suas prestaçóes, cada vez mais tem direito a crédito nas próximas compras, assim como lhe é possível dividi-la em um número maior de vezes. Nos últimos tempos, a rede adotou as tendências das demais redes varejistas e se associou a um banco. A partir daí, começou a oferecer cartôes de crédito da loja aos seus clientes, que podem ser usados dentro e fora delas. Com esses cartôes, é possível parcelar as compras sem a incidência de juros. 
A compreensão das despesas atuais de Sônia depende, por sua vez, do acompanhamento da trajetória de sua vida. A presença/ausência das mais diversas quantidades e valores de dinheiro em determinado momentos de sua vida, como este, é que acaba configurando certas situaçóes nas quais dívidas se fazem presentes, assim como as estratégias de viração em períodos de necessidade.

Há pouco tempo, Sônia teve a chance de adquirir uma casa maior. É claro que não possuía todo o montante desejado para a compra da casa à vista (doze mil reais). Decidiu, entâo, fazer um empréstimo no banco em que trabalhava. $\mathrm{O}$ banco lhe concedeu apenas dois mil reais de empréstimo, e sua patroa lhe emprestou mais mil e quinhentos reais (para ir descontando aos poucos de seu salário).

Com a venda da casa, Sônia adquiriu mais oito mil reais. Com o que tinha na poupança, conseguiu inteirar os doze mil reais. No entanto, a casa precisava de alguns reparos. Como ainda tinha por volta de mil reais guardados, ela resolveu comprar os materiais de construção e dividir o pagamento em quatro vezes no cartão (quatro parcelas de quatrocentos reais) e usar o dinheiro para despesas extras. Sônia gasta por volta de quinhentos reais em supermercado todos os meses.

De casa nova, Sônia não esperou quitar algumas dívidas. Decidiu comprar um fogão e uma coifa novos, além de um conjunto de sofá nas Casas Bahia. Ao todo, gastou por volta de mil reais, divididos em dez parcelas mensais de cento e nove reais - o que significou mais uma dívida que precisa ser arcada mensalmente.

Todos esses gastos já se igualam ao salário de Sônia. A grande questão que se faz é: como ela consegue dar conta de comprar comida, pagar as parcelas do cartáo e ainda pagar o empréstimo do banco, que passará três anos pagando parcelas de cento e vinte e seis reais mensais? A resposta é bem simples: ela não consegue, de fato.

O que ocorre é que gasta mais do que ganha e, na hora de pagar as faturas dos cartóes, não paga o valor integral, mas o mínimo ou um pouco mais do que o valor exigido para o que cartáo seja "liberado" e ela possa continuar usando-o. Assim, paga juros extras, o que acaba aumentando muito o valor final de suas contas". Um exemplo é como faz com as compras de supermercado. Sônia possui três cartôes diferentes. Se um cartáo está cheio de despesas, Sônia paga o pouco exigido e procura não comprar mais nada naquele cartão por alguns meses. Enquanto isso, vai usando os outros dois alternadamente, de modo que possa continuar comprando até que o cartáo anterior esteja livre de despesas.

Aí entende-se o porquê de guardar os inúmeros cartóes recebidos - os adicionais enviados sem solicitaçáo - para momentos de emergência, o que já é uma quantia que a ajuda bastante, considerando o que ganha e os gastos que possui.

II Trata-se, aqui, da utilização de um elemento existente no mecanismo dos cartôes não só de crédito, mas também de lojas - o chamado crédito rotativo. Tal mecanismo possibilita pagar apenas a parcela mínima exigida pela fatura e deixar o restante para o mês seguinte, acrescido de juros - os chamados "encargos contratuais". O crédito rotativo vem sendo utilizado pela maioria das famílias em situaçóes em que a fatura não pode ser paga integralmente ou porque se gastou mais do que se poderia gastar no cartão ou porque se privilegiou o pagamento de outras contas. 
Da mesma forma, para Lúcia, há meses em que as coisas apertam mais e ela tem que se virar para dar conta de pagar os gastos. É aí que entram seus cartôes. Sáo eles que permitem a ela dar conta das despesas, quando as coisas não vão bem. Se ela gastou mais do que deveria em um mês, se a fatura vier com um valor que ela náo pode pagar integralmente, ela paga a taxa mínima exigida pelo cartáo e não o utiliza durante o mês inteiro, para poder dar conta de pagar a fatura que virá com juros no próximo mês. Com isso, tenta se virar com o que tem de dinheiro em mãos, mas, caso as despesas exijam mais do que ela possui, passa a usar outro cartão. No meio de todos esses apertos, consegue sobreviver e tocar as dívidas para frente.

$\mathrm{L}$ - É uma vantagem e ao mesmo tempo não é, porque se, às vezes, você ultrapassa o limite...

$-\mathrm{O}$ que acontece?

L - Daí aperta, você paga metade; no outro mês, paga a outra metade e aí vai...

Embora os gastos de Lúcia e Sônia não cheguem a ultrapassar sua renda, suas vidas seriam mais difíceis se elas tivessem que possuir o dinheiro em mãos para todas as suas despesas mensais. Com os cartóes conseguem prolongar os pagamentos para o mês seguinte. A margem de manobra que têm com a renda obtida é, dessa forma, maior. O que acontece, entáo, é que o salário que recebem a cada mês acaba servindo para pagar despesas do mês anterior. É mediante esse pagamento que conseguem "liberar" o cartấo para fazer mais gastos.

Com suas possibilidades de parcelamento e limites "generosos", parecem ter acentuado um processo de postergaçáo de dívidas e de aquisição presente e pagamento futuro, de forma que os cálculos feitos para administrar os recursos e a renda obtida parecem não ter como previsão fechar o caixa sem despesas, mas, sim, usar essa reserva de crédito com cautela, com administração dos limites dos créditos concedidos, para poder dar continuidade à postergação dos pagamentos. Éa partir da execuçáo correta desses cálculos que muitos conseguem lidar com o parco orçamento, somando aos recursos existentes o "crédito" definido no limite dos cartóes.

Desse modo, os dados colhidos em campo permitem afirmar que o fenômeno da emergência dos cartôes requalifica o consumo popular, inserindo o que se pode chamar de "financeirização" nas dinâmicas cotidianas. Trata-se, em primeiro lugar, de poder contar com a possibilidade de parcelamento das compras no cartão em várias vezes sem juros e com o adiamento do pagamento da fatura para o próximo mês ou para os meses seguintes - a troco do pagamento de juros.

Ao possibilitarem aos seus possuidores dispor da existência de um valor fictício a mais todo mês, o limite de crédito desses cartôes acaba se tornando incluso em parte do orçamento doméstico em si, o que significa que as famílias já calculam seus orçamentos contando com a presença desta "renda a mais". Daí a enorme proliferaçáo desses artefatos, pois constituem, para muitos, a forma mais rápida e segura de contar com um dinheiro extra em momentos de necessidade.

Esses elementos, entre outros, fazem os cartôes serem objetos quase que indispensáveis na garantia da aquisição dos mais diversos bens, tendo em vista as condiçôes da renda mensal dos 
entrevistados. A chegada da "financeirizaçâo" parece, assim, ter alterado em grande medida o gerenciamento do orçamento doméstico, pois permite às famílias contar com uma margem de cálculo maior para gastos, multiplicar os recursos disponíveis e, consequentemente, os bens adquiridos e as despesas.

\title{
FINANCEIRIZAÇÃO E PRÁTICAS DE ENDIVIDAMENTO CONTÍNUO
}

\begin{abstract}
"Ah, é melhor, se pudesse ir lá comprar em dinheiro, mas sempre não dá, né? Tem outras coisas pra comprar, não dá pra você ir lá comprar a dinheiro, comprar tudo a dinheiro. Eu faço isso, vou lá, compro uma quantidade no cartáo que dê, aí eu pago no outro mês, já faço outra compra."
\end{abstract}

Lúcia

Espera-se que as situaçóes narradas tenham demonstrado como a ampla utilização dos cartôes aponta para uma mudança de patamar nas práticas das populaçóes pauperizadas. Esses artefatos vieram para mostrar que há a possibilidade de consumir, com a mediação por meio da qual é possível gerenciar o orçamento, com maior liberdade de ação e ampliando a aquisiçáo de bens, para quem aprende a utilizar o crédito.

Ao que tudo indica, então, as reconfiguraçóes engendradas pelos artefatos de crédito possibilitam novos jogos de relaçóes entre rendimentos, crédito e dívidas, que, por sua vez, abrem possibilidades de contatos com o sistema financeiro e com as "vantagens" por ele oferecidas. A gestáo da renda obtida mensalmente e a organizaçáo do orçamento das famílias passaram a ser regidas a partir de outra lógica, mais mercantilizada, com base nas regras dos mercados e pautadas em prazos estabelecidos pelas faturas dos cartóes.

É esse ciclo de pagamento de faturas - liberação do cartão - e novas compras que caracteriza o orçamento de muitos entrevistados. Um aperto aqui e outro ali possibilitam que se feche o mês gastando o essencial e pagando as prestaçóes de juros dos cartóes e dos crediários abertos. Então, espera-se que a quitação dessas dívidas ocorra sem intempéries, para que novas aquisiçóes sejam feitas, e, com elas, as dívidas, restabelecidas.

Mas nem todos conseguem lidar de forma harmônica com esse sistema. Sabe-se, na verdade, que ele foi concebido pensando em lucrar com a má utilizaçáo de mecanismos como o crédito rotativo. Basta observar as altas taxas de juros presentes nos crediários existentes, nos cartōes de crédito, assim como nos diversos cartôes fornecidos pelas financeiras para perceber como grandes estratégias e todo um sistema de pagamento são montados em cima da escassez de recursos das pessoas e suas possibilidades (ou não) de quitação das dívidas.

Trata-se de uma lógica que incita ao consumo sem que se possua a certeza de que será possível quitar a dívida realizada, por meio de estratégias que passam pela definiçấo das formas de 
pagamento, pelos juros altíssimos embutidos nas prestaçóes; ainda mais altos quando se trata de atrasos e inadimplências.

Não é raro que muitos detentores de cartôes não consigam utilizar os mecanismos de crédito aos quais têm acesso sem caírem em dívidas, uma vez que as informaçóes sobre juros e suas taxas, em caso de atraso de pagamento, são colocadas de forma propositadamente confusa, ou seja, feitas de maneira difícil de lidar, sendo complicado calcular se há dívida e quanto se está devendo, quando se atrasa algum número de dias.

A ausência de qualquer instância capaz de fornecer informaçóes claras sobre os mecanismos de crédito consiste em outro ponto favorável ao argumento de que se trata de toda uma lógica que aciona e promove o endividamento das pessoas.

A relação específica que os entrevistados têm com as dívidas contraídas e com o comprometimento de seu "nome" é outro fator interessante a ser ressaltado. Ao que parece, ter o "nome sujo" já não é uma situação tão alarmante e tampouco uma mácula para muitos.

É claro que o acesso a certos bens fica comprometido, ao se depender exclusivamente das transações no próprio nome, mas isso não evita, de forma alguma, o consumo de bens, pelo fato de existirem mecanismos que garantem a participação no mercado de consumo. É o caso dos cartôes e cheques anteriormente solicitados e que, se permanecem sem dívidas, podem ser usados, mesmo que haja dívidas em outras instâncias. Dessa forma, o consumo continua a ocorrer e não depende exclusivamente da forma legal exigida pelo mercado.

Outros devedores nem se intimidam com os juros exorbitantes que as dívidas atingem e tampouco se preocupam em pagá-las, uma vez que sabem que as redes varejistas e as outras lojas os querem como clientes e que logo oferecerão um perdão ou uma renegociaçáo da dívida em valores bem menores ${ }^{12}$.

Ana Cristina, 45 anos, por exemplo, está com o "nome sujo" há algum tempo na rede de supermercados Compre Bem. A dívida começou quando ficou desempregada e não conseguiu pagar as faturas.

A rede Compre Bem lhe envia frequentemente propostas de renegociação de dívidas.

Pude presenciar a chegada de uma dessas propostas de quitação das dívidas. Cristina estava devendo mais de cento e vinte reais no cartão Compre Bem, mas, se pagasse quarenta e sete reais, teria a dívida perdoada. Ela não pagou, e, em uma visita realizada alguns meses depois, a oferta havia diminuído de quarenta e sete reais para trinta e quatro reais.

Entre os entrevistados, poucos foram aqueles que não estavam com uma dívida no momento ou não estiveram alguma vez com o "nome sujo". A frequência com que a falta de recursos impossibilita a quitação de dívidas já feitas é impressionante. Aqui entram motivos distintos: de

I2 Geralmente, a rede Casas Bahia espera o prazo de meses após o não pagamento das prestaçóes ou carnês para enviar uma proposta de renegociaçáo. Igualmente, supermercados como o Compre Bem e outras redes varejistas, ao enviarem a fatura de vencimentos em seu cartão, com os juros acrescidos pelo não pagamento da dívida, enviam, após alguns meses, uma fatura com dois valores: o primeiro referente a quanto o cliente deve a eles e o segundo com um valor de perdão da dívida sugerido por eles, geralmente $75 \%$ mais barato que o primeiro valor. Já quando a dívida é com bancos, não há muito o que fazer, se não renegociá-la ou esperar cinco anos para sua quitação. 
um lado, os acasos da vida - as circunstâncias imprevisíveis do emprego e do desemprego, da saúde e da doença, etc. -; de outro lado, emprestar o cartâo ou o cheque - e, consequentemente, o "nome" - a um vizinho, parente ou amigo, que não cumpre o dever de pagar o "empréstimo virtual", constituindo outro gerador de endividamentos. Sem qualquer mecanismo de proteção financeira, muitos se veem endividados de uma hora para outra, pela falta de recursos trazidos por esses eventos aleatórios.

Assim, enquanto estiverem empregadas, Lúcia e Sônia conseguirão, bem ou mal, dar conta de suas dívidas, mas basta uns dois meses sem receberem seus salários ou ocorrer emergência de qualquer outro evento que desvie o dinheiro a ser utilizado no pagamento para outra despesa para que toda essa gestáo equilibrada dos gastos domésticos se transforme em uma bola de neve de dívidas.

É nesse sentido que se poderia arriscar a hipótese de que, na verdade, no atual contexto de propagação da lógica do endividamento para amplas parcelas da populaçáo, não é necessário o pagamento integral das pequenas dívidas de todos os consumidores endividados. É claro que se procura fazer de tudo para que as dívidas sejam quitadas, e os juros correspondentes, pagos, mas, quando se percebe que o credor não tem condiçôes de arcar com os juros, acaba-se oferecendo a ele uma série de "descontos" e "promoçôes" para que a dívida possa ser paga e que ele possa voltar a frequentar a rede para continuar consumindo.

Mais importante do que a dívida em si é o número de pessoas envolvidas em operaçōes e em seu volume, ainda que náo venham a ser completadas antes da quitação dos valores das compras. Essa quitaçáo e seu valor parecem não valer muito quando se trata de compras de pequeno porte, realizadas em redes varejistas ${ }^{13}$.

O necessário, então, é manter as pessoas cativas nos fluxos financeiros, enquanto clientes das redes e lojas, portadoras e utilizadoras de seus cartóes, ou seja, mantendo a aquisiçấo de produtos, contanto que paguem uma parte irrisória de suas dívidas. Entre outras estratégias de mercado aqui já citadas para capturar esses "clientes em potencial", esta constitui-se como da mais extrema relevância, pois revela até que ponto chegou o processo de financeirizaçẫo da pobreza.

\section{CONSIDERAÇÕES FINAIS: DESCONSTRUINDO DICOTOMIAS}

As cenas apresentadas permitem supor que se esteja realmente diante de um fenômeno novo. Trata-se de outras formas de organização e gestáo das vidas, de outro conjunto de relaçôes entre consumo, crédito, renda e dívidas e que altera igualmente as relaçóes no interior das famílias, bem como as formas de sociabilidade.

Mais do que isso, ao seguir os artefatos, as mediaçôes com outros objetos e a superposição de situaçóes e ao analisar, por meio de cenas, os efeitos da financeirização e as práticas que a partir dela se constituem, pôde-se notar que os fluxos da riqueza financeirizada (e do capital, portanto) não estáo apartados, mas, ao contrário, estáo conectados, em vários nós, aos chamados

I3 Isso não ocorre, porém, quando se trata de dívidas feitas em bancos ou financeiras. 
espaços de pobreza, na própria medida em que está na lógica desse capital expandir o mercado e incorporar essas populaçôes por meio das práticas de consumo.

São essas mediaçôes que permitem vislumbrar o quanto, na verdade, não se está diante de dicotomias - os excluídos e os incluídos à chamada "sociedade de consumo"; o consumo local (geralmente tido como mais paralelo) e o consumo global. Consequentemente, a partir do momento em que se trabalha com essa justaposiçáo de fenômenos geralmente tidos como separados - como o consumo da pobreza e os fluxos globais do capital financeiro -, acaba-se por extinguir dicotomias que serviam para separar o campo empírico da situação na qual está imerso, como exclusão e inclusão social, local e global, pobreza e riqueza.

Assim, o estudo das práticas populares de consumo nấo pode ser concebido como isolado dos padrōes globalizados, e a periferia, por sua vez, náo pode ser concebida como espaço da pobreza e de carência apenas. Cabe, entáo, questionar a forma e o sentido de uma situaçáo que não deixa de ser de pobreza (em razão das condiçôes de moradia e da escassez de recursos), mas que convive com padrôes globalizados e financeirizados de consumo.

É nesse sentido que a realização de uma etnografia multissituada pretende contribuir, ao postular a necessidade de uma abordagem que descarte as dicotomias global e local, pois, ao levar em consideração mediaçóes, artefatos e vínculos existentes nas situaçōes sociais, por meio das diferentes perspectivas, os detalhes, os fatores e as conexóes, geralmente tidos como contraditórios, fazem sentido (LAUSER, op. cit.). Isso significa que as conexôes deixam de ser trabalhadas nos termos de oposiçóes.

Isso, por sua vez, supóe a necessidade de se reverem as categorias analíticas e os parâmetros descritivos para lidar com questôes que definiram a pauta dos estudos urbanos nas últimas décadas - cidade e periferias urbanas, pobreza, exclusão e segregação, práticas populares, modos de vida, etc. -, a partir de uma perspectiva que enquadre os desafios recentes. É no sentido de "abrir as portas" para esses novos estudos que este trabalho espera ter contribuído.

\section{FONTES CONSULTADAS}

Burawoy, Michael. Global ethnography: forces, connections, and imaginations in a postmodern world. Berkeley: University of California Press, 2000.

Clifford, James. "Sobre la alegoría etnográfica." In: Marcus, George; Clifford, James. Retoricas de la antropologia. Madrid: Júcar Universidad, 199r.

Gille, Zsuza; O’Riain, Seán. Global ethnography. Annual Review Sociological, v. 28, pp. 271-95, 2002.

Latour, Bruno. Une sociologie sans objet? Note théorique sur l'interobjectivité, 1994. Disponível em: <http://www.bruno-latour.fr/articles/article/057.html>. Acesso em: 22/10/2008. 
Factures/Fractures from the concept of network to that of attachment. Res Special Issue on Factura, n. 36, pp. 20-3I, autumn 1999. Disponível em: <http:/www.bruno-latour.fr/articles/ article/76-FACTURE-GB.pdf $>$. Acesso em: 22/10/2008.

Lauser, Andrea. Translokale Ethnographie [47 Absätze]. Forum Qualitative Sozialforschung, v. 6, n. 3, art. 7, 2005. Disponível em: <http://nbn-resolving.de/urn:nbn:de:0II4-fqso50374>. Acesso em: 03/10/2008.

Lepetit, Bernard. "Sobre a escala na história." In: Revel, Jacques (Org.) Jogos de escalas. A experiência da microanálise. Rio de Janeiro: Fundação Getulio Vargas, 1996.

Marcus, George E. O que vem (logo) depois do "PÓS": o caso da etnografia. Revista de antropologia, São Paulo, USP, v. 37, pp. 7-34, 1994.

Ethnography in/of the world system: the emergence of multi-sited ethnography. Annual Review of Anthropology, Palo Alto, California, v. 24, pp. 95-II7, 1995.

. "Ethnography in/of the world system: the emergence of multi-sited ethnography". In: Marcus, George E. Ethnography through Thick/Thin. Princeton: Princeton University Press, 1998.

Queiroz, Renata S. B. de. Processo de tomada de decisão na aquisição de crédito e preferências entre alternativas de financiamento no varejo. 2007. Dissertação (Mestrado) - Departamento de Administração da Faculdade de Economia, Administração e Contabilidade da Universidade de São Paulo, São Paulo, 2007.

SAntos, Kauê Lopes dos. Uma financeirização da pobreza? O sistema financeiro e sua capilaridade no circuito inferior da economia urbana na cidade de São Paulo. 2007. Graduação (Trabalho de Conclusão Individual) - Departamento de Geografia da Faculdade de Filosofia, Letras e Ciências Humanas da Universidade de São Paulo, São Paulo, 2007.

Scıré, Cláudia. Uma etnografia multissituada das práticas populares de consumo. 2009. Dissertação (Mestrado) - Programa de Pós-Graduação em Sociologia da USP, São Paulo, 2009.

Telles, Vera da Silva; Cabanes, Robert (Orgs.) Nas tramas da cidade: trajetórias urbanas e seus territórios. São Paulo: Humanitas, 2006.

Trajano Filho, Wilson. Que barulho é esse, o dos pós-modernos? Anuário Antropológico, Editora da Universidade de Brasília, pp. I33-I5I, I988.

Viveiros De Castro, Eduardo. O nativo relativo. Revista Mana, Rio de Janeiro, UFRJ, v. 8, n. I, pp. II3-I48, 2002.

Zerrenner, Sabrina A. Estudo sobre as razóes para o endividamento das pessoas de baixa renda. 2007. Dissertação (Mestrado) - Departamento de Administração da Faculdade de Economia, Administração e Contabilidade da Universidade de São Paulo, São Paulo, 2007. 